\title{
Secondary School Mathematics Teachers' Pedagogical Views on the Concept and Teaching of Place Value
}

\author{
Kamuran TARIM ${ }^{1}$, Ayten SIYER ${ }^{2 *}$
}

${ }^{1}$ Çukurova University, Faculty of Education, Adana, Turkey

${ }^{2}$ Ministry of Education, Maltepe Esenkent Secondary School, Istanbul, Turkey

\begin{tabular}{l} 
ARTICLE INFO \\
\hline Article History: \\
Received \\
23.11 .2016 \\
Received in revised \\
form 08.02 .2017 \\
Accepted \\
17.03.2017 \\
Available online \\
30.06.2017
\end{tabular}

\begin{abstract}
In this article, it was tried to determine the awareness of secondary school mathematics teachers about the difficulties of their students on 'place value' and their views and opinions on the teaching approaches that might be implemented to overcome these difficulties. The study sample consisted of nine mathematics teachers working at middle schools in Adana and Gaziantep from lower, middle and upper socioeconomic levels. This study used case study model. Clinical interview method was used for data collection. In the interview, there were 5 main questions and 2 questions related to the misconceptions the teachers faced in their teaching experience. Findings of the study show that teachers have similar thoughts to identify the difficulties their students have and the misconceptions they have developed with the concept of place value, but present different teaching approaches to overcome these difficulties and misconceptions.

(C) 2017 AUJES. All rights reserved

Keywords:

Place value, mathematics education, concept of number
\end{abstract}

\section{Extended Abstract}

\section{Purpose}

The value in the place of ciphers composing of a number is called place value. This term is one of the most basic characteristic of number system and arithmetic and again the most abstract terms. The great majority of mistakes that the students make in the arithmetic operations is caused by this term (Artut ve Tarım, 2006). The literature researches about place value show that there is a lack of the basic-conceptual and useful side of learning the term of place value and also a conception testing the understanding of this term. The students' thinking systematics, learning styles, the difficulties that they will have in the learning of different mathematical subjects, the mistakes that the students will make and the prior knowledge needed for the learning target subject should be analyzed by the teachers.

\footnotetext{
*Corresponding author's address: MEB, İlköğretim Mathematic Teacher, Şanlıurfa, Turkey 
It can be said that the knowledge and thoughts of the teachers to realise an effective education are quite important for the form of suitable learning-teaching environments (Beyazit ve Aksoy, 2010). The purpose of this study is that the difficulties of the students in the understanding of place value and the opinions of the teachers within their pedagogical knowledge in the subject about which suitable teaching strategies that will be able to be used to be up to these difficulties are analyzed.The application process of this study may increase the level of awareness of theparticipants by prompting to thinking. It is expected that the achievement of the students in the subject of place value is increased by arranging suitable lesson environment and using different teaching methods and techniques related to the subject. It is necessary that the pedagogical views and opinions of the teachers about the subject in which the suitable teaching approaches may be what to overcome the difficulties that the students have while learning the term of place value and the mistakes that they make related to this term are known. In this context it is tried to find an answer for the question" what are the views and opinions of the primary school mathematic teachers in the subject of realizing the difficulties that the students have about place value and the suitable approaches to be applied to overcome these difficulties.

\section{Method}

In this study, case study model which is qualitative research method has been used. The data have been had from semi-structured interviews with nine experienced mathematic teachers in their fields. The participants as part of research; teacher $(T)$, gender (W:woman, M:man), The kind of school (S: state, P: private), Licence(B: banchelor's degree, P: post graduate), seniority (Sn)" T\{G.S.L.\}S have been coded. Example coding T\{W.P.B.\}5 states that woman working at a private secondary school, having bachelor's degree and 5 years seniority is a teacher. The clinical interview which is one of the qualitative research methods has been used as method of data collection. Before starting to the interview, the information about the purpose of the study has been given to the teachers and get permission from them to use recorder during the interview by short meeting. An extensive literature review has been made while forming the questions and the research made by Arslan and Ubuz(2009) has been made use of. At the same time, the questions that will be used in the reasearch have been stated by being discussed whether they serve their purpose or not with two lecturers and two teachers. In the interview, 7 questions have totally been used. 5 of them are about the opinions related to the difficulties that the students have in the subject of place value, the reasons of these difficulties and teaching approaches to be used to fix the reasons and the rest is about the mistakes related to this subject that the teachers face in their teaching lives. The data had from the clinical interviews with teachers have been analyzed by using qualitative methods. The data recorded with recorder has been gotten down and 
analyzing process has been carried on these written documents.Descriptive analysis method has been used with the purpose of finding the meanings in the teachers' oral and written answers. The data had in the first step of the analysis have been summarized and interpreted according to themas stated beforehand. In the second step, the data has been read and arranged according to the outline formed beforehand. In the third step, arranged data has been defined and supported by thedirect quotations in the necassary places. In the last step, defined findings have been explained, associated and given the meaning.

\section{Results}

The teachers has displayed quite different approaches to overcome difficulties and mistakes stated in the study. 7 teachers have stated that they prefer to link with terms and teaching the basic information that the teachers tell in the kinds of resource by questioning and with a critical view and reasons. 2 teachers T\{M.S.B.\}34 and T\{W.S.B 77 has chosen a rutin and classical method as the explaining of theoritic information on given questions, review of the subjects when it is time. In general, while 7 teachers states that they use discovery teaching method which is compatible with constructivist approach, 2 teachers has displayed typical behaviorist teaching approach.

\section{Discussion and Conclusion}

Findings shows that teachers have similar knowledge and ideas about difficulties they might encounter on learning of place value and determining the mental causes of this difficulties. Therewithal, findings shows that teachers have different approaches in teaching of the subject related to student's difficulties and misconceptions on area of place value. Bayazit ve Aksoy, (2010) stated although there is no opportunities to follow the international literature by teachers so at the end they can be developed all this knowledge from their professional life observations and pedagogical content intensive intellectual activities to be undertaken on ways of student's thoughts. As a result, the vast majority of mistakes in arithmetic by students are caused by understood poorly of place value which is most important subject of number system and arithmetic by students. Therefore, while teaching new concepts about mathematics, teachers should check students preliminary information, misconceptions should be identified and after the elimination of student's misconceptions, they should start teaching (Yenilmez ve Yılmaz, 2008). In this context teachers are strongly advised to stand on the concept of place value. 


\title{
Ortaokul Matematik Öğretmenlerinin Basamak Değer Kavramı ve Öğretimine İlişkin Pedagojik Görüşleri
}

\author{
Kamuran TARIM ${ }^{1}$, Ayten SIYER ${ }^{2^{*}}$
}

${ }^{1}$ Çukurova Üniversitesi, Eğitim Fakültesi, Adana, Türkiye

${ }^{2}$ Milli Eğitim Bakanlığı, Maltepe Esenkent Ortaokulu, İstanbul, Türkiye

MAKALE BİLGİ

Makale Tarihçesi:

Alındı 23.11.2016

Düzeltilmiş hali

alındı 08.02.2017

Kabul edildi

17.03.2017

Çevrimiçi yayınlandı

30.06.2017

\section{ÖZET}

Bu makalede, ortaokul matematik öğretmenlerinin 'basamak değeri' konusundaki öğrenci zorluklarını fark etme ve bu zorlukların üstesinden gelmeleri için uygulanabilecek öğretim yaklaşımları konusundaki görüş ve düşünceleri belirlenmeye çalışılmıştır. Araştırmanın örneklemini alt, orta ve üst sosyoekonomik düzeydeki Adana ve Gaziantep iline bağlı ortaokullarda görev yapan dokuz öğretmen oluşturmaktadır. Bu çalışmada nitel araştırma yöntemlerinden örnek olay çalışma modeli kullanılmıştır. Veri toplamak için nitel çalışma yöntemlerinden klinik mülakat yöntemi kullanılmıştır. Mülakatta 5 ana soru ve öğretmenin öğretmenlik yaşantısında konu ile ilgili karşılaştığı yanılgılara ilişkin 2 soru olmak üzere toplam 7 soru kullanılmıştır. Çalışmanın bulguları öğretmenlerin, öğrencilerinin basamak değer kavramı ile ilgili karşılaştıkları zorluklar ve geliştirdikleri yanılgıları teşhis etmede benzer düşüncelere sahip olduklarını, ancak bu zorlukların ve yanılgıların giderilmesi için farklı öğretim yaklaşımları sergilediklerini göstermektedir.

(C) 2017 AUJES. Tüm hakları saklıdır

Anahtar Kelimeler:

Basamak değeri, matematik eğitimi, sayı kavramı

\section{Giriş}

Sayı kavramı bireyin kendisi tarafından yapılandırdığı bir kavramdır. Piaget ve arkadaşları, sayı kavramını; bireyin, ilişkileri oluşturarak ve düzenleyerek yapılandırdığını düşünmüşlerdir (Akt. Kaplan, 2008, s.1). Günümüzde kullanılan 10 tabanlı sayı sisteminin temelini Hint-Arap sayma sistemi oluşturur. Bir sayıyı oluşturan rakamların bulunduğu yerdeki değerine basamak değer denir. Bu kavram sayı sisteminin ve aritmetiğin en önemli özelliklerinden ve yine en soyut kavramlarından biridir. Çocukların aritmetik işlemlerde yaptıkları hataların da büyük çoğunluğu bu kavramdan kaynaklanır (Dinç Artut ve Tarım, 2006, s.27). Basamak değeri konusunda öğrenci zorluklarını ve kavram yanılgılarını inceleyen çok sayıda çalışma bulunmaktadır (Kamii, 1982; Thompson, 2002; Dinç Artut ve Tarım, 2006; Bayazit ve Aksoy, 2010). Bu çalışmalar incelendiğinde basamak değerinin öğrenciler tarafından sağlıklı algılanmasını zorlaştıran asıl neden sıfırın basamakta yer tutucu 
olması özelliği ve kullandığımız sistemin yazı dilinde ve sözel dilde farklılık göstermesidir. Rakamın basamak ve sayı değeri ve on ile kısa çarpmada öğrenciler yanlış düşüncelere sahip olmaktadırlar. Diğer bir yandan öğrenciler, en uzun sayı en büyük sayıdır, ondalık sayının inmal edildiği düşünce ve ondalık sayılarda ondalık yerler arasındaki ilişkileri belirlemede güçlükler yaşamaktadırlar. Öğrencilerin bu yanlış inançları ve deneyimleri sonucu ortaya çıkan davranışlar kavram yanılgıları olarak tanımlanmaktadır (Yenilmez ve Yaşa, 2008, s.463).

Öğrenciler, yukarda kısa bir özeti sunulan zorlukların üstesinden gelmeleri ve içeriksel açıdan doğru ve zengin basamak değeri bilgileri edinmek için öğretmenlerin yardım ve rehberliğine intiyaç duymaktadırlar. Öğretmenler bu yardım ve rehberliği, matematiksel kavramların öğrencilere etkin olarak nasıl öğretilebileceğine yönelik bilgileri kapsayan alan eksenli pedagoji bilgileri ile sağlamaktadırlar. Alan odaklı pedagoji bilgisinin kapsamı fazlasıyla geniş olduğundan, öğretmenlerin öğretim programı ve ders kitaplarını anlayış şekilleri, matematik konularına uygun sunuş şekillerinin (grafikler, tablolar, v.s.) seçimi ve kullanımı, öğrencilerin bir konuyla ilgili bilgilerinin ölçme ve değerlendirilmesinin nasıl yapılacağı, öğrencilerin öğretim yaşamlarındaki bilgi birikimleri ve bu bilgilerin yeni konuların öğretiminde nasıl kullanılabileceği gibi çok farklı alanlardaki öğretmenlerin bilgi ve düşüncelerini içermektedir (Dede, Bayazit ve Soybaş, 2010, s.68). Araştırmalar, öğretmenlerin sahip olduğu konu alan bilgisinin pedagojik alan bilgisiyle ilişkili olduğunu; iyi konu alan bilgisine sahip olan öğretmenlerin öğrencilerin sahip olduğu öğrenme güçlüklerinin, kavram yanılgılarının farkında olduğunu, bunları gidermek için gerekli olan yöntem-strateji bilgisine sahip olduğunu ve müfredat bilgilerinin de daha gelişmiş olduğunu ortaya koymaktadır (Van Driel et al., 2001).

Bugüne kadar "basamak değeri" ile ilgili pek çok araştırma yapıldığı görülmüştür(Kamii, 1982; Thompson, 2002; Dinç Artut ve Tarım, 2006; Bayazit ve Aksoy, 2010). Basamak değeri ile ilgili literatür araştırmaları, basamak değer kavramını öğrenmenin temel-kavramsal ve kullanışlı yönünün, ayrıca bu kavramı anlamayı test eden bir anlayış eksikliğinin olduğu görülmektedir. Aynı zamanda basamak değer kavramının öğretimine ilişkin sınıf içinde yaşanan durumların, ilgili matematiksel kavramların ve en önemlisi de öğrenci ürünlerinin analiz ve betimlenmesini sağlayan analiz modellerinin ortaya konulması gerekmektedir. Öğrencilerin nasıl bir düşünme sistematiği geliştirdikleri ve öğrenme stilleri, farklı matematiksel konuların öğreniminde karşılaşabilecekleri zorluklar, oluşturabilecekleri yanılgılar ve kısıtlı algılar ve hedef konunun öğrenimi için ihtiyaç duyulan ön bilgiler ile ilgili öğretmenlerin sahip oldukları bilgi ve düşüncelerin uygun öğrenme-öğretme ortamlarının oluşturulabilmesi için oldukça önemli olduğu söylenilebilir (Bayazit ve Aksoy, 2010, s.703). Basamak değeri kavramının öğrencilerin matematikteki diğer kavramları anlamalarına ve farklı matematik düşünceleri arasında bağlantı kurmalarına, matematiksel düşünme, akıl yürütme, çıkarım yapma, tümdengelimci argümanlar geliştirme becerilerinin gelişmesine, daha ileri matematik kavramlarının öğrenilmesine taban oluşturduğu çok değişik araştırmalarda ve NCTM gibi dünyanın saygı duyduğu ve faydalandığı dokümanlarda belirtilmektedir (Kaplan, 2008, s.6). Bu 
çalışmanın amacı öğrencilerin basamak değerini anlamadaki zorlukları ve bu zorlukların giderilmesi için uygun öğretim yaklaşımlarının neler olabileceği konusundaki öğretmenlerin pedagojik alan bilgileri dahilinde görüşlerinin incelenmesidir.

Bu çalışmanın uygulama süreci katılımcıları düşünmeye sevk ederek farkındalık düzeylerini artırabilir.Araştırma sonucunda elde edilen bulgular ışığında uygun ders ortamları düzenlenerek ve konu ile ilgili farklı öğretim yöntem ve tekniklerinden yararlanılarak öğrencilerin basamak değer konusundaki başarılarının arttırıması umulmaktadır.

Öğrencilerin basamak değeri kavramını anlamadaki zorlukları, bu düşünceye ilişkin geliştirdikleri kavram yanılgıları ve zorlukların giderilmesi için uygun öğretim yaklaşımlarının neler olabileceği konusundaki öğretmenlerin pedagojik görüş ve düşüncelerinin bilinmesi gerekmektedir. Bu bağlamda, "Illköğretim matematik öğretmenlerinin 'basamak değer' konusundaki öğrenci zorluklarını fark etme ve bu zorlukların üstesinden gelmeleri için uygulanabilecek öğretim yaklaşımları konusundaki görüş ve düşünceleri nelerdir?" sorusuna yanıt aranmaya çalışımıştır.

\section{Yöntem}

\section{Araştırma Deseni}

$\mathrm{Bu}$ çalışmada nitel araştırma yöntemlerinden örnek olay çalışma modeli kullanılmıştır. Nitel araştırmanın en belirgin özelliği, üzerinde araşııma yapılan kişilerin bakış açılarıyla araştırma yapılan olay, olgu, norm ve değerlerin incelenmeye çalışılmasıdır (Ekiz, 2004). Örnek olay çalışması ise güncel olayları gerçek bağlamda incelediğinden (Erduran ve Yeşildere, 2010) çalışmada bu araştırma stratejisi kullanılmıştır. Sunulan veriler meslekte tecrübeli dokuz ortaokul matematik öğretmeniyle yapılan yarı yapılandırılmış mülakatlardan elde edilmiştir. Mülakatta öğrencilerin basamak değeri konusunda yaşadıkları zorluklar, bunların sebepleri ve düzeltilmesi için uygulanabilecek öğretim yaklaşımları ile ilgili öğretmenlerin düşüncelerine ilişkin 5 soru ve öğretmenin öğretmenlik yaşantısında konu ile ilgili karşılaşı ı̆̆ yanılgılara ilişkin 2 soru olmak üzere toplam 7 soru kullanılmıştır. Veri toplama yöntemi ve mülakatta kullanılan soruların güvenilirlik ve geçerliliğini sağlamak için soruların literatürden faydalanılarak geliştirilmesine ve soruların amaca hizmet edip etmediğinin alan uzmanlarıyla tartışılmasınadikkat edilmiştir.

\section{Çalışma Grubu}

Katılımcılar, Adana ve Gaziantep illerinde bulunan ortaokullar arasından "tesadüfî küme örnekleme" (Simple Random Sampling) yoluyla seçilmiştir. Alt, orta ve üst sosyoekonomik düzeydeki Adana iline bağlı 1, Gaziantep iline bağlı 5 okul olmak üzere toplam 6 ortaokulda görev yapan 9 öğretmen belirlenerek, araştırma kapsamına alınmıştır.

Araştırma kapsamında öğretmenlerin kişisel bilgileri aşağıdaki Tablo 1'de sunulmuştur.

Tablo 1.Katıımcıların demografik özellikleri 


\begin{tabular}{|c|c|c|c|}
\hline & & \multicolumn{2}{|c|}{ Katılımcilar } \\
\hline & & Kadın & Erkek \\
\hline \multirow{4}{*}{ Yaş } & $20-30$ & 3 & 2 \\
\hline & $31-40$ & - & 1 \\
\hline & $41-50$ & 1 & 1 \\
\hline & $51-60$ & - & 1 \\
\hline \multirow[t]{2}{*}{ Okul Türü } & Devlet & 4 & 3 \\
\hline & Özel & - & 2 \\
\hline \multirow[b]{2}{*}{ Mezumiyet } & Lisans & 3 & 4 \\
\hline & $\begin{array}{l}\text { Yüksek } \\
\text { Lisans }\end{array}$ & 1 & 1 \\
\hline \multirow{4}{*}{ Kıdem } & $1-5$ & 1 & 1 \\
\hline & $6-10$ & 2 & 1 \\
\hline & $11-15$ & - & 1 \\
\hline & $16-25$ & 1 & 2 \\
\hline
\end{tabular}

Araştırma kapsamındaki katılımcılar; Öğretmen (Ö), Cinsiyet (K:kadın, E:erkek), Okul türü (D:devlet, Ö:özel), Lisans durumu (L:lisans mezunu, YL: yüksek lisans mezunu), Kıdem (Kd) olmak üzere

Ö\{C.O.L.\}Kd

şeklinde kodlanmıştır.

Örnek kodlama;

Ö\{K.Ö.L.\}5 tkadın, Özel bir ortaokulda görev yapıyor, Lisans mezunu, 5 yıllık kıdeme sahip olan öğretmen.

\section{Verilerin Toplanması}

Veri toplama yöntemi olarak nitel çalışmalarda sıkça kullanılan klinik mülakat yöntemi kullanılmıştır. Matematik eğitiminde klinik mülâkatların amacı, öğrencilerin stratejilerini, bilgi yapılarını veya becerilerini karakterize etmek ve belirli bir öğretimin etkililiğini araştırmak, gelişim sürecini daha iyi anlamak veya problem çözme davranışlarını araştırmaktır ( Karataş ve Güven, 2003). Klinik mülakatlar sayesinde öğretmenlerin 'basamak değer' konusundaki öğrenci zorluklarını fark etme ve bu zorlukların üstesinden gelmeleri için uygulanabilecek öğretim yaklaşımları konusundaki görüş ve düşünceleri ortaya konulmaya çalışılmıştır.

Klinik mülakata uygun olarak öğretmenlerin uygulama ile ilgili düşüncelerini birinci elden alma ve problemleri derinlemesine irdelemek için öğretmenler ile bireysel görüşmeler yapılarak çalışmanın verileri oluşturulmuştur. Mülakata başlamadan önce öğretmenlerle kısa görüşmeler yapılarak çalışmanın amacı hakkında bilgi verilmiş ve mülakat esnasında ses kayıt cihazı kullanmak için izinleri alınmıştır. Bu çalışmada yürütülen mülakatlar, sessiz bir ortamda bireysel olarak gerçekleştirilmiştir. Her bir mülakat, yaklaşık olarak 20-30 dakika arasında sürmüştür. Mülakat sırasında sorular öğretmenlere teker teker yöneltilmiş ve konuyla ilgili 
düşüncelerini açıklamaları istenilmiştir. Aynı zamanda klinik mülakatları daha sonradan analiz edilmek üzere ses kayıt cihazına kaydedilmiştir.

\section{Veri Toplama Aracı}

Yanlış cevabın bulunması, öğrencinin nerede zorlandığı ile ilgili yeterli bilgi vermeyebilir (Karataş ve Güven, 2003). Bu açıdan kullanılan klinik mülâkat araştırmacıya öğretmenlerin yardımı ile bu noktaların belirlenmesinde yardımcı olur. Soruların oluşturulmasında kapsamlı bir literatür taraması yapılmış ve Ubuz ve Arslan'ın (2009) yapmış olduğu araştırmalardan yararlanılmıştır. Aynı zamanda soruların amaca hizmet edip etmediği alan uzmanlarıyla tartışılarak araştırmada kullanılacak sorular belirlenmiştir.

Mülakatta öğrencilerin basamak değer konusunda yaşadıkları zorluklar ve bu zorlukların nedenleri ve düzeltilmesi için kullanılabilecek öğretim yaklaşımları ile ilgili öğretmenlerin düşüncelerine ilişkin 5 sorukullanılmıştır.

Eldeki çalışmada kullanılan birinci soru;ondalık sayılarda basamak değeri ile ilgili öğrencilerin yaşadıkları zorluklar, bunların sebepleri ve düzeltilmesi için uygulanabilecek öğretim yaklaşımları ile ilgili öğretmenlerin düşüncelerini araştırmak için kullanılmıştır.

S.1) Sekizinci sınıflarda ondalık sayılarda çıkarma işleminin kullanıldığı bir soru çözülürken tahtaya yazdığınız;

$$
0,73
$$

0,6431

çıkarma işlemi için; bir öğrencinizin işlemin cevabının negatif çıkacağı konusunda ısrarcı davrandığını gözlüyorsunuz. Sizce öğrencinizin yanılgısının sebebi nedir? , Bu durumda neler yapabilirsiniz?

Bazı öğrenciler "en uzun sayı en büyük sayıdır" gibi yanlış bir algı geliştirmişlerdir. Bunun sebepleri arasında; uzun dizge düşüncesi $(4,63>4,8)$, pay odaklı düşünme $(6,3=6,03$, çünkü ikisi de 6 tam ve 3 parça, parçaların boyutu (onda 3 , yüzde 3) göz ardı edilir), ters düşünme (ondalık sayıların tam sayıları temsil ettiğine ancak tersten yazıldığını düşünürler; 0,163=1 tane on, 6 tane yüz, 3 tane bin), sıfırın küçük yaptığını düşünme (virgülden sonra ilk basamakta sıfır veya birden fazla sıfır varsa o sayı küçüktür, bunun dışındaki durumlarda uzun olan sayı büyüktür), sağ taraf taşmış düşüncesi (120=12 tane on ise 0,12 de onda 12'dir) bulunmaktadır (Baki ve Güç, 2014).

S.2) Altıncı sınıflarda uzunluk ölçü birimleri konusunu işledikten sonra ders sonu etkinliği olarak sınıfa getirdiğiniz boy ölçme çubuğunu kullanan iki öğrenci yanınıza gelerek "Öğretmenim, benim boyum 1,42cm Gizem'in boyu ise $1,43 \mathrm{~cm}$. Eğer ben $10 \mathrm{~cm}$ daha uzun olsaydım Gizem ile aynı boyda olacaktım." ifadesindeki öğrenci yanılgısının sebebi nedir? , Bu durumda neler yapabilirsiniz? 
Öğrenciler arasında basamak değer kavramı ile ilgili sıkça karşılaşılan bir diğer güçlük ondalık sayılarda ondalık yerler arasındaki ilişkileri belirlemede yaşanmaktadır. Toplama ve çıkarma gerektiren problemlerde basamak değeri veya ondalık kısımdaki basamakların yerleri dikkate alınmadan noktadan sonraki son basamaktan toplama ve çıkarma yapıldığını göstermektedir (Ubuz ve Arslan, 2009, s.113).

S.3) Altıncı sınıfta ondalık sayılarda çarpma işlemi ile ilgili alıştırmalar yaparken "2,37 x 10" sorusuna öğrencilerin bir kısmı hiç düşünmeden "2,370" cevabını vermiştir. Bu öğrencilerin yanılgılarının sebepleri nelerdir? , Bu durumda neler yapabilirsiniz?

Basamak değeri kavramı ile ilgili sık sık karşılaşılan güçlüklerden bir tanesi de 10 ile çarpmayla ilgili ortaya çıkan güçlüklerdir. Thompson (2003) "bir sayıyı 10 ile çarptığımızda ne olur?" sorusunu ister ortaokul, ister ortaöğretim veya lise ve hatta öğretmen yetiştiren kurumlarda soralım cevabın "sayının sonuna 0 eklersin" olacağını belirtmektedir. Bu yanılgı tam sayılarla çarpma işleminde doğru sonuca ulaşmayı sağlarken, ondalık sayılarda tam aksine yanlış bir ifadeye neden olmaktadır (Varol ve Kubanç, 2012). Örneğin $25 \times 10=250$ iken $1250 \times 10=125$ çıkmaktadır.

S.4) Altıncı sınıf öğrencilerinizden 'üç bin kırk iki' sayısını yazmalarını istediğinizde öğrencilerden birkaçının 342 veya 300042 gibi yanlış yanıtlar verdiklerini gördünüz. Bu öğrencilerin yanılgılarının sebepleri nelerdir? , Bu durumda neler yapabilirsiniz?

Normalde hiçliği ifade etmek için kullanılan sıfırın basamakta önemli bir yer tutucu özelliğinin olması öğrenciler tarafından zorlukla algılanabilmektedir (Ubuz ve Arslan, 2009, s.111). Onluk sistem yazımından farklı olarak sıfırın basamaktaki yeri diğer basamakların doğru yerlerinin belirlenmesi açısından önemlidir. Zorlukların çoğunluğu sayı sistemimizin konuşma ve yazma şeklinin farklı olmasından kaynaklanmaktadır ( Fuson ve Bariars, 1990).

S.5) Ders esnasında tahtaya yazdığınız "545 sayısının çeşitli basamaklarında kullanılan 5'lerin basamak değerleri toplamı kaçtır?" araştırma sorusu için birkaç öğrenci 10 yanıtını vermiştir. Öğrencinin yanılgısının sebepleri nelerdir? , Bu durumda neler yapabilirsiniz?

Öğrencilerden beklenen basamak değer tanımı "Bir sayıyı oluşturan rakamların bulunduğu yerdeki değeri." şeklindedir (Yenilmez ve Demirhan, 2013). Ancak basamak değeri ile ilgili karşılaşılan bir diğer güçlük rakamın basamak ve sayı değerlerinin ayırt edilememesidir. Bir rakamın sayı değeri her zaman aynıken, basamak değeri sayı içerisindeki yerine göre değişir (Arslan, Yıldız ve Yavuz, 2011). Sayıdaki bir rakamın basamak değeri, o rakamın sayı değeriyle bulunduğu hanenin değerinin çarpımı sonucu bulunur.

Ayrıca çalışma kapsamında öğretmenin öğretmenlik yaşantısında konu ile ilgili karşılaştığı yanılgılara ilişkin aşağıdaki 2 soru daha kullanılmıştır. 
* Sizde öğretmenlik yaşantınızda basamak değer konusu ile ilgili size yöneltilen sorulara benzer kavram yanılgılarına rastlıyor musunuz? rastlıyorsunuz?

* Basamak değer konusunda hangi tür yanılgıya daha çok

\section{Verilerin Analizi}

Toplanılan verilerin analizinde kuramsal çerçeve olarak Shulman"ın (1986) pedagojik alan bilgisi düşüncesi kullanılmıştır ( Bayazit ve Aksoy, 2010). Shulman'ın (1986) pedagojik alan bilgisi tanımında iki faktörönem kazanmıştır:

1-Öğrenci güçlükleri

2-Öğretim stratejileri ve temsilleri

Farklı araştırmacıların pedagojik alan bilgisinin bileşenlerini nasıl ele aldıklarını inceleyen Park ve Oliver (2008) bu iki bileşeni esas aldıklarını ve fakat bunlarla birlikte "ölçme-değerlendirme bilgisi" ve "öğretim programında kavramların ele alınışı hakkında sahip olunan bilgi" gibi yeni bileşenleri de tarif ettiklerini rapor etmiştir.

$\mathrm{Bu}$ çalışmada öğretmenlerin pedagojik alan bilgileri iki boyutu itibariyle incelenmiştir. Bunlardan birincisi öğrencilerin basamak değeri kavramını anlamadaki zorlukları, geliştirdikleri kavram yanılgıları ve bunların zihinsel sebeplerine ilişkin öğretmenlerin görüş ve düşüncelerini içermektedir. İkincisi ise bahsedilen zorlukların giderilmesi için uygulanabilecek etkin öğretim yaklaşımlarına ilişkin öğretmenlerin görüş ve düşüncelerini içermektedir.

Öğretmenlerle yapılan klinik mülakatlardan elde edilen veriler nitel yöntemler kullanılarak analiz edilmiştir. Ses kayıt cihazına kaydedilmiş olan veriler yazıya dökülmüş ve analiz işlemleri bu yazılı dokümanlar üzerinden yürütülmüştür. Öğretmenlerin ifadeleri, öğrencilerin sahip oldukları yanılgılara ilişkin; en uzun sayı en büyük sayıdır, ondalık sayılarda ondalık yerler arasındaki ilişkileri belirleme, 10 ile çarpmayla ilgili ortaya çıkan güçlükler, sıfırın basamakta yer tutucu özelliğini kavrayamama ve rakamın basamak ve sayı değerlerinin ayırt edilememesi kategorilerinde toplanmıştır. Bu kategorilerle ilgili ayrıntılı bilgiler veri toplama aracı kısmında mevcuttur.

Öğretmenlerin yazılı ve sözlü yanıtlarındaki anlamlara ulaşılması amacıyla betimsel analiz yöntemi kullanılmıştır. Analiz işleminin birinci aşamasında elde edilen veriler daha önceden belirlenen temalara/kategorilere göre özetlenmiş ve yorumlanmıştır. İkinci aşamada daha önce oluşturulan çerçeveye göre elde edilen veriler okunmuş ve düzenlenmiştir. Üçüncü aşamada düzenlenen veriler tanımlanmış ve gerekli yerlerde doğrudan alıntılarla desteklenmiştir. Son aşamada ise tanımlanan bulgular açıklanmış, ilişkilendirilmiş ve anlamlandırılmıştır.

\section{Bulgular ve Yorum}

$\mathrm{Bu}$ kısımda öğretmenlerin pedagojik alan bilgileri beş soru üzerinden incelenecektir. 


\section{Birinci sorudan elde edilen bulgular}

Birinci soru öğrenciler arasında sıkça rastlanılan "en uzun sayı en büyük sayıdır ve ondalık sayının ihmal edildiği düşünce" yanlış algısının sebepleri ve öğrencilerdeki bu güçlüğün giderilmesinde öğretmenlerin kullandığı yöntemlere ilişkin öğretmenlerin düşüncelerini araştırmayı hedeflemiştir.

Öğretmenlerin çoğunluğu birincisorudaki öğrenci yanılgısının nedenini "en uzun sayı en büyük sayıdır ve ondalık sayının ihmal edildiği düşünce" olarak belirtmişlerdir. Aynı zamanda, Ö\{K.D.YL\}5 ve Ö\{E.D.L\}34 öğrencilerin ondalık sayıları karşılaştırmada, Ö\{E.D.L\}6 ve Ö\{K.D.L\}20 basamakları eşitlemede öğrencilerin zorluklar yaşadıklarını belirtmişlerdir. Ayrıca, Ö\{E.Ö.YL\}16 öğrencilerin sınavlara yönelik çalışmasından dolayı ilk önce çıkarma işlemini yapıp daha sonra virgülü koymak gibi pratik kullanma alışkanlıklarından böyle bir yanılgı geliştirdiklerini vurgulamıştır. Ö\{E.Ö.YL\}4 ise öğretmenin öğrenciyi ezbere iten bir tavır sergilemesinden dolayı öğrencilerin bu tarz yanılgılar geliştirdiklerini belirtmiştir.Ö\{K.D.YL\}5öğretmenin yanılgının nedeni ile ilgili görüşünü şu şekilde ifade etmektedir:

"Yapılan hata basamak sayısının yani basamak sayısı derken sayının uzunluğuna bakıp 0,6431 sayısını daha büyük bir sayı olarak düşünebilir. Hatta 0,73 sayısından 0,6431 sayısının çıkmayacağını bile söyleyebilir."

Öğretmenlerin çoğunluğu, öğrencilerin bu yanılgıları karşısında çıkan sayıda boş kalan yerlere sıfır koyarak öğrenciye işlemi tekrar çözdürteceklerini dile getirmişlerdir. Bunun yanı sıra, Ö\{K.D.YL\}5 ve Ö\{K.D.L\}20 ondalık sayılarda basamak değer konusunu, Ö\{K.D.L\}7 ise ondalık sayılarda karşılaştırma konusunu öğrenciye kısa bir anlatımla hatırlatacaklarını belirtmişlerdir. Ö\{E.D.L\}6, soruyu ilk önce virgülsüz olarak daha sonra virgüllü olarak çözdürüp aradaki farkı öğrencinin kendisinin görmesini sağlayacağını belirtmiştir. Ö\{E.Ö.YL\}16 virgülleri alt alta yazmaları gerektiğini vurgulayacağını belirtmiş ve farklı bir yol olarak öğrencilerden sayıyı kesir haline çevirip bu şekilde çözmelerini isteyeceğini söylemiştir. Ö\{E.D.L\}12 ise yine virgülleri alt alta yazmaları gerektiğini vurgulayarak öğrencilerdeki bu güçlüğü örnekler üzerinde göstererek gidermeye çalışacağını belirtmiştir. Ö\{E.D.L\}34 daha fazla örnek çözerek yanılgıyı gidereceğini belirtmişken, Ö\{E.Ö.YL\}4 ise sayıyı kesir haline çevirip bu şekilde çözmelerini isteyeceğini dile getirmiştir. Ö\{E.D.L\}6öğretmeninkonu ile ilgili görüşünü şu şekilde ifade etmektedir:

"Boş kalan yerlere sıfır koymasını söyler, işlemi tekrar yapmasını isterim... Genelde sayınınhangisininbüyük olduğunu öğrenciye sorarım. Virgülsüz olarak sorup daha sonra virgüllü uygulamasını isterim."

\section{İkinci sorudan elde edilen bulgular}


İkinci soru öğrencilerdeki "ondalık sayılarda ondalık yerler arasındaki ilişkileri belirleyememe" yanlış algısının sebepleri ve öğrencilerdeki bu güçlügün giderilmesinde öğretmenlerin kullandığı yöntemlere ilişkin öğretmenlerin düşüncelerini araştırmayı hedeflemiştir.

Öğretmenlerin çoğunluğuikincisorudaki öğrenci yanılgısının nedenini "ondalık sayılarda ondalık yerler arasındaki ilişkiyi belirleyememe" olarak belirtmişlerdir. Aynı zamanda, öğrencilerin bu yanılgısı ile ilgili Ö\{K.D.YL\}5 öğrencilerin basamak değer konusunu tamamen anlayamadıklarını belirtmişken Ö\{K.D.L\}9 ise öğrencilerin basamak isimlerini bilmemelerinden kaynaklandığını belirtmiştir. Ö\{E.Ö.YL\}16 ondalık sayıların okunuşunda yapılan hataların öğrencileri bu tarz yanılgılara itebileceğini dile getirmiştir. Ö\{E.D.L\}12 ise öğrencinin ezberci yöntemi benimsemiş olduğundan dolayı basamaklar arasındaki dönüşümü göremediklerini vurgulamıştır. Ayrıca, Ö\{E.Ö.YL\}4 denklem sistemi zihniyetinin çocuklara tam olarak öğretilmediği için muhakeme yeteneklerinin gelişmediğini belirtmiştir.Ö\{K.D.L\}9öğretmenininyanılgının nedeni ile ilgili görüşünü şu şekilde ifade etmektedir:

"Burada ondalık sayılarda basamakların karıştırılması söz konusu. Buradaki asıl yanılgının sebebi sayının son basamağından başlayarak onda birler yüzde birler olarak gitmelerinden kaynaklanıyor."

Öğretmenlerin çoğunluğu, öğrencilerin bu yanılgıları karşısında uzunluklar arasındaki farkı görsel olarak göstererek öğrencilerin muhakeme yapmalarına olanak sağlayacaklarını belirtmişlerdir. Bunun yanı sıra, Ö\{K.D.YL\}5 basamakdeğer tablosunu kullandığını belirtmiştir. Ö\{K.D.L\}7 ve Ö\{K.D.L\}9 ise basamak değer konusunu kısa bir hatırlatma ile öğrencilerdeki bu yanılgıyı giderebileceklerini dile getirmişlerdir. Ö\{E.Ö.YL\}4 günlük hayattan örnekler vererek öğrencilerdeki bu güçlüğü giderebileceğini belirtmiştir.Ö\{K.D.YL\}5 öğretmenininkonu ile ilgili görüşünü şu şekilde ifade etmektedir:

"Ondalık sayılar ile ilgili tablolar var. Ondalık sayılarda basamak değerini anlatırken bu tablolardan oluşturuyoruz... Virgülden sonra onda birler yüzde birler binde birler şeklinde ayırıp bu tabloları küçük notlar halinde sınıfa dağıtıyorum."

\section{Üçüncü sorudan elde edilen bulgular}

Üçüncü soru öğrencilerdeki "on ile kısa çarpma" yanlış algısının sebepleri ve öğrencilerdeki bu güçlüğün giderilmesinde öğretmenlerin kullandığı yöntemlere ilişkin öğretmenlerin düşüncelerini araştırmayı hedeflemiştir.

Öğretmenlerin tümü öğrencilerde daha önceden öğrencinin ilköğretim birinci kademe yıllarından getirmiş olduğu "on ile kısa çarpmada sayının sonuna sıfırekleriz" düşüncesinden hareketle böyle bir yanılgı sergilediği görüşünü dile getirmişlerdir. Bunun yanı sıra Ö\{K.D.L\}20 ders anlatım sırasında öğretmene göre önemli olan konunun ilk önce verilmesi gibi konu anlatım sırasındaki düzenin bozulduğu durumlarda bu yanılgıların meydana gelebileceğini 
belirtmiştir.Ö\{E.Ö.YL\}16öğretmenininyanılgının nedeni ile ilgili görüşünü şu şekilde ifade etmektedir:

"Öğrencilere kısa yoldan çarpma anlatırken 'sayının 10 ile çarpımında sayının sonuna sıfır ekleyin' diyoruz ama öğrenci ondalık sayılarda da bunu kullanıyor. Ancak ondalık sayılarda virgül kaydırması gerekir ama öğrenci ezbere gittiği için sayının sonuna bir sıfır eklemiş."

Öğretmenlerin çoğunluğu, öğrencilerin bu yanılgıları karşısında baştan tekrar formal bilginin düzeltilmesi gerektiği görüşünü bildirmişlerdir. Bunun yanı sıra, Ö\{E.D.L\}6 verilen ondalık sayıyı kesir şeklinde yazmalarını isteyerek işlemi bir daha yapmalarını isteyeceğini belirtmiştir. Ö\{K.D.L\}20, Ö\{K.D.L\}9 ve Ö\{E.Ö.YL\}16 ise bu yanılgıуı günlük hayattan seçilen örnekler üzerinde virgülün önemini vurgulayarak ve karşılaştırma yaptırarak giderilebileceğini belirtmişlerdir. Bu görüşü destekler nitelikte Ö\{K.D.L\}20 öğretmenininkonu ile ilgili görüşünü şu şekilde ifade etmektedir:

"Ben altıncı sınıflarda ondalık sayılarda çarpma işlemini anlatırken, 'virgülü parka götürüyoruz gibi' deyişlerle virgül üzerinde durmaya çalışıyorum... Daha çok günlük hayatlarından örneklemeye çalışıyorum. Yani 'bakkaldan bir tane elma aldın on tane daha alman gerekiyor, ne yaparsın' gibi gerçek hayattan yola çıkarak konuyu kavratmaya çalışıyorum."

\section{Dördüncü sorudan elde edilen bulgular}

Dördüncü soru öğrencilerdeki "sıfırın basamakta yer tutucu olması özelliği ve kullandığımız sistemin yazı dilinde ve sözel dilde farklılık göstermesi” yanlış algısının sebepleri ve öğrencilerdeki bu güçlüğün giderilmesinde öğretmenlerin kullandığı yöntemlere ilişkin öğretmenlerin düşüncelerini araştırmayı hedeflemiştir.

Öğretmenlerin çoğunluğu öğrencinin ilköğretim birinci kademe yıllarında sayıların okunuşu-yazılışı konusunu ve sıfırın basamakta yer tutucu olması özelliğini kavrayamadıklarını dile getirmişlerdir. Ö $\{$ K.D.YL\}5 öğrencilerin bu konuda alıştırma eksikliklerinin olduğunu vurgulamıştır. Ö\{E.D.L\}34 ise yazı dili ile sözel dilin farkııı̆ının öğrenciyi bu tarz yanılgılara götürebileceğini vurgulamıştır. Ö\{K.D.L\}20 ve Ö\{E.Ö.YL\}16 bu yanılgıyı geliştiren öğrencilerin basamak ve sayı kavramlarını anlamadıklarını belirtmişlerdir.Ö\{E.D.L\}34 öğretmenininyanılgının nedeni ile ilgili görüşünü şu şekilde ifade etmektedir:

“Öğrenciye 'üç bin kırk iki' yi yaz dediğimizde bazı öğrenciler 3000 i ve 42 iyi ayrı yazıyorlar. Ama birleştirmesini istediğimizde bazen 342 yazıyorlar bazen de 300042 yazıyorlar. Bunun nedeni öğrenci araya sıfır koymayı unutuyor. Öğrenci sıfırın basamaktaki değerini atlıyor. "

Öğretmenlerin çoğunluğu, öğrencilerin bu yanılgıları karşısında farklı örnekler üzerinde sıfırın değerli olduğunu öğrencilere göstereceklerini belirtmişlerdir. Ö\{K.D.YL\}5 okulda bulunan birlik, yüzlük, binlik kartları sınıfa getirerek öğrencilerdeki 
bu yanılgıyı görsel olarak gidermeye çalışacağını dile getirmiştir. Ö\{E.D.L\}6, öğrencinin yanlış yazdığı sayıyı çözümlemesini isteyerek öğrencinin yaptığı hatayı kendisinin görmesini sağlayacağını belirtmiştir. Ö\{E.D.L\}34 ise öğrencinin konu ile ilgili daha çok alıştırma yapmasını sağlamada ailenin önemi üzerinde durmuştur. Bu görüşü destekler nitelikteÖ\{E.D.L\}34 öğretmenininkonu ile ilgili görüşünü şu şekilde ifade etmektedir:

"Öğrenciye daha çok alıştırma yapmalarını söylerim. Mesela evlerinde ebeveynler bu tür sayılar söyleyerek çocuğun yazmasını sağlayabilir."

\section{Beşinci sorudan elde edilen bulgular}

Beşinci soru öğrencilerdeki "rakamın basamak ve sayı değerlerinin ayırt edilememesi"yanlış algısının sebepleri ve öğrencilerdeki bu güçlüğün giderilmesinde öğretmenlerin kullandığı yöntemlere ilişkin öğretmenlerin düşüncelerini araştırmayı hedeflemiştir.

Öğretmenlerin tümü sorudaki öğrenci yanılgısının nedenini "rakamın basamak ve sayı değerinin ayırt edilememesi” olarak belirtmişlerdir. Ö $\{K . D . Y L\} 5$ öğretmenininyanılgının nedeni ile ilgili görüşünü şu şekilde ifade etmektedir:

“Öğrencimiz burada basamak değeri ile sayının sayı değerlerini karıştırıyor. Basamak değerinde sayı basamaktaki değerleriyle alınır sayı değerinde ise sayının sayısal değeri alınır. Öğrenci bu iki ayrımı fark etmemiştir. "

Öğretmenlerin çoğunluğu, öğrencilerin bu yanılgıları karşısında basamak değer konusunu kısa bir şekilde izah ettikten sonra farklı örnekler üzerinde basamak ve sayı değerinin farklılığını öğrencilere göstereceklerini belirtmişlerdir. Ö\{E.D.L\}12 ise her basamağın kendine ait bir değeri olduğunu öğrenciyi tahtaya çıkararak verilen sayıyı heceleyerek okumasını isteyeceğini ve böylece öğrencinin kendi hatasını kendisinin görebileceğini dile getirmiştir. Ö\{K.D.L\}20 öğrencinin yaşadığı bu güçlük karşısında diğer öğrencilerin yapılan hataya ilişkin fikirlerini hatayı yapan öğrenci ile bire bir iletişimde bulunmalarını sağlayarak akran eğitimi yaklaşımını sergilediğini belirtmiştir. Ö\{E.Ö.YL\}16 ise basamak değer konusunu öğrenciye anlatmadan önce konu ile ilgili internetten edindiği bir slayt gösterisi ile ilk olarak öğrencilerde merak uyandıracağını daha sonra ise konu anlatımına geçeceğini belirtmiştir. Bu görüşü destekler nitelikte Ö\{E.Ö.YL\}16 öğretmenininkonu ile ilgili görüşünü şu şekilde ifade etmektedir:

"Ben bunun için çok güzel bir slayt gösterisi edindim. Bunu internetten çok kolay bir şekilde edinebiliyorsunuz. Yaklaşık bir veya iki dersinizi alıyor ama çocuğun kafasına gerçekten oturuyor. Slayt, matematiğin tarihçesinden başlıyor Yunanların kullandığı düzeni, Roma rakamlarının gizemi, Çinlilerin kullandığı sistemi eğlenceli bir yolla anlatıyor. Mesela Çinliler 1 bölünemediği için erkek sayıdır, 2 bölünebildiği için dişidir. Asal 
sayıları maço erkekler olarak nitelendiriliyor. Çocuklara bunu en başta bu şekilde oyun gibi sevdirebilirseniz merak uyandırabiliyorsunuz. Sonrasında ise anlatmak istediğiniz konuları kolayca öğrenciye aktarabiliyorsunuz."

\section{Öğretmenlerin öğretmenlik yaşantılarında konu ile ilgili karşılaştığı farklıkavram yanılgılarına ilişkin bulgular}

Öğretmenlere sorulan "Sizde öğretmenlik yaşantınızda bunlara benzer kavram yanılgılarına rastlıyor musunuz?" sorusuna öğretmenlerin tümü olumlu yanıtlar vermişlerdir. Bunun yanı sıra Ö\{E.D.L\}6 ve Ö\{K.D.L\}7 öğrencilerin basamak değer kavramının eksikliğinden oluşan ondalık sayılarda ve tam sayılarda bölme işlemlerinde güçlükler yaşadıklarını dile getirmişlerdir. Bu görüşü destekler nitelikte Ö\{K.D.L\}7 öğretmeninin konu ile ilgili görüşünü şu şekilde ifade etmektedir:

"Bunların dışında genellikle bölme ile ilgili hatalar yapıyorlar. Özellikle sayıda sıfır varsa öğrenci bunu hiç yapamıyor, sağlamasını da düşünmüyor."

Öğretmenlere sorulan "Hangi tür yanılgıya daha çok rastlıyorsunuz?" sorusuna öğretmelerin çoğunluğu basamak değeri kavramının eksikliğinden kaynaklanan ondalık sayılar konusundaki alıştırmalarda öğrencilerin sıklıkla güçlük yaşadıklarını belirtmişlerdir. Bu görüşü destekler nitelikte Ö\{K.D.L\}9 öğretmenininkonu ile ilgili görüşünü şu şekilde ifade etmektedir:

“Öğrenci rakamın basamak değerini kavramakta güçlük çekiyor.

$\mathrm{Bu}$ nedenle ondalık kesirlerde büyüklük küçüklük kavramı, virgülleri alt alta yazmada sorunlar oluyor."

Bir diğer Ö\{E.D.L\}12 öğretmeninin konu ile ilgili görüşünü şu şekilde ifade etmektedir:

"En çok ondalık sayılarda toplama yaparken virgüllerin yerlerini karıştırıyorlar, aynı isimli basamaklar alt alta yazmıyorlar. Bu da çocukların basamak değer kavramının tam olarak özümsenmemesinden kaynaklanıyor. "

Bununlabirlikteçalışmada bahsedilen zorlukların ve yanılgıların üstesinden gelmeleri için öğrencilere yapılabilecek açıklamalar ve uygulanabilecek etkin öğretim modelleri konularında öğretmenler oldukça farklı yaklaşımlar sergilemişlerdir. Ö\{K.D.YL\}5， Ö\{E.D.L\}6， Ö\{K.D.L\}20， Ö\{K.D.L\}9， Ö\{E.Ö.YL\}16， Ö\{E.D.L\}12， Ö\{E.Ö.YL\}4 kavramlar arası ilişkilendirmeler yapmayı ve kaynak çeşitliliği içerisinde anlattıkları öz bilgileri; sorgulayarak ve eleştirel bir bakış açısıyla, nedenleriyle, öğretmeyi tercih etmişlerdir. Ö\{E.D.L\}34 ve Ö\{K.D.L\}7 teorik bilgilerin verilen sorular üzerinden sözel ifadelerle açıklanması, yeri geldiğinde konuların tekrarı gibi çok daha rutin ve klasik bir yol izlemişlerdir. Genel olarak Ö\{K.D.YL\}5, Ö\{E.D.L\}6, Ö\{K.D.L\}20, Ö\{K.D.L\}9, Ö\{E.Ö.YL\}16, Ö\{E.D.L\}12, Ö\{E.Ö.YL\}4 yapılandırmacı yaklaşımın felsefesiyle uyum arz eden buluş yoluyla öğretim modelini kullanırken Ö\{E.D.L\}34 ve Ö\{K.D.L\}7 tipik bir davranışçı öğretim yaklaşımı sergilemiştir. 
Çalışmada kullanılan sorular; basamak değeri ile ilgili öğrencilerin yaşadıkları zorluklar, bunların sebepleri ve düzeltilmesi için uygulanabilecek öğretim yaklaşımları ile ilgili öğretmenlerin düşüncelerini araştırmak için kullanılmıştır. Ses kayıt cihazına kaydedilmiş olan veriler yazıya dökülmüş ve analiz işlemleri bu yazılı dokümanlar üzerinden yürütülmüştür.

\section{Sonuç ve Tartışma}

Basamak değeri ile ilgili ortaokul öğrencilerinin yaşadıkları zorluklar, bunların sebepleri ve düzeltilmesi için uygulanabilecek öğretim yaklaşımları ile ilgili öğretmenlerin düşüncelerini saptamak amacıyla bu çalışma planlanmıştır.

Bulgular katılımcı öğretmenlerin, öğrencilerin basamak değer konusunu öğrenirken karşılaşabilecekleri zorluklar ve bu zorlukların zihinsel sebeplerini teşhis etme noktasında oldukça benzer bilgi ve düşüncelere sahip olduklarını göstermektedir. Aynı zamanda çalışmanın bulguları basamak değer konusu bağlamında öğrenci zorlukları ve yanılgılarına ilişkin öğretmenlerin konunun öğretim boyutunda farklı yaklaşımlar sergileyebileceklerini de göstermektedir.

Örneğin, öğretmenlerin tümü basamak değer konusu ile bağlantılı olan "on ile kısa çarpmada sayının sonuna sıfır ekleriz" yanılgısının öğrencilerde daha önceden öğrencinin ilköğretim birinci kademe yıllarından getirmiş olduğu tam sayılarda on ile kısa çarpma bilgilerini revize etmeden ondalık sayılar konusuna aktarmalarından kaynaklandığını belirtmişlerdir. Bu sonuç Thompson'un (2003) çalışmasının sonuçları ile paralellik göstermektedir. Thompson (2003) "bir sayıyı 10 ile çarptığımızda ne olur?" sorusuna ister ilköğretim, ister ortaöğretim veya lise ve hatta öğretmen yetiştiren kurumlarda soralım cevabın "sayının sonuna 0 eklersin" olacağını belirtmektedir. Benzer şekilde Brown'un (1981) yapmış olduğu çalışmada bazı öğrencilerin 5,13 × 10 sorusuna 5,130 cevabını verdikleri görülmektedir. Öğretmenler öğrencideki bu yanılgı karşısında farklı yaklaşımlar sergilemişlerdir. Öğretmenlerin bir kısmı tekrar formal bilginin düzeltilmesi gerektiğini savunmuşlardır. Diğer kısım ise bu yanılgıyı günlük hayattan seçilen örnekler üzerinde virgülün önemini vurgulayarak ve karşılaştırma yaptırarak giderebileceklerini belirtmişlerdir. Bir başka yaklaşım olarak öğretmenler ondalık sayıyı kesir şeklinde yazmalarını isteyerek işlemi bir daha yapmalarını sağlayacaklarını dile getirmişlerdir. Bu bağlamda ikinci kısımdaki öğretmenlerin yaklaşımlarının basamak değer konusunun esasını ve özelliklerini anlama bağlamında daha etkili olabileceği öngörüsünde bulunulabilir.

Öğretmenlerin çoğunluğu en uzun sayı en büyük sayıdır ve ondalık sayının inmal edildiği düşünceye ilişkin öğrenci yanılgısını irdelerken, iki görüş belirtmişlerdir. Birincisi; öğrencilerin ondalık sayıları karşılaştırmada yaşadıkları güçlükler ikincisi ise basamakları eşitlemede yaşadığı güçlüklerin öğrenciyi bu yanılgıya götürdüğü öngörüsünde bulunmuşlardır. Aynı zamanda öğretmenlerin belirttiği öğrencilerin sınavlara yönelik çalışması ve öğretmenin öğrenciyi ezbere iten bir tavır sergilemesi öğrencilerde bu yanılgının gelişmesine neden olabilmektedir. Steinle (2004) ondalık sayılarla ilgili yaptığı çalışmasında "(4,8 ve 4,75$)$ ile $(4,3$ ve 4,65$)$ sayı çiftlerindeki sayılardan en büyüğünü işaretleyin" sorusu için bir öğrenci ilk durumda 4,75 (yanlış) 
ve ikinci durumda 4,65 (doğru) olarak yanıtlamıştır. Bu bağlamda araştırmanın bu bulgusu Steinle'nin bulgularını destekler nitelikte olduğu söylenebilir. Öğretmenlerin bir kısmı öğrencilerdeki bu yanılgıyı gidermek için, soruyu ilk önce virgülsüz daha sonra virgüllü olarak çözdüreceklerini veya virgülleri alt alta yazmaları gerektiğini vurgulayarak örnekler üzerinde çalışacaklarını belirtmişlerdir. Aynı zamanda çıkan sayıda boş kalan yerlere sıfır koyarak öğrenciye işlemi tekrar çözdürteceklerini veya sayıyı kesir haline çevirip bu şekilde çözmelerini isteyeceklerini dile getirmişlerdir. Diğer kısım öğretmenler ise ondalık sayılarda basamak değer ve ondalık sayılarda karşılaştırma konularını kısa bir hatırlatma ile öğrencideki bu yanılgıyı giderebileceklerini belirtmişlerdir. Bu bağlamda birinci kısım öğretmenlerinin buluş yoluyla öğretim stratejisini kullanarak öğrencilerin bilgiye ulaşmalarını kolaylaştıracak alternatifler sundukları ve uygun öğrenme ortamları oluşturmaya çalıştıkları şeklinde yorumlanabilir.

Yine öğretmenler rakamın basamak ve sayı değeri kavramının öğrenim ve öğretimine ilişkin benzer düşünceleri dile getirmişler ve öğrenciler tarafından rakamın basamak ve sayı değerinin ayırt edilemediğini vurgulamışlardır. Kamii (1986) Amerika Birleşik Devletleri, Kanada ve İsviçre'deki araştırmaların sonuçlarına dayanarak 1. ve 2. sınıfta bulunan öğrencilerin çoğunluğunun 16'daki 1'in 1 tane onluk gösterdiğini anlamadıklarını ifade etmektedir (Ubuz ve Arslan, 2009, s.108). Bu bağlamda araştırmanın bu bulgusu Kamii'nin bulgularını destekler nitelikte olduğu söylenebilir. Öğretmenlerin çoğunluğu öğrencideki bu yanılgıyı düzeltmek için basamak ve sayı değer arasındaki farkılıkları örnekler üzerinde göstereceklerini dile getirmişlerdir. Bir öğretmen ise öğrencideki bu yanılgının nedenine ilişkin diğer öğrencilerin fikirlerini sorarak sınıf içi iletişimde bulunacağını vurgulamıştır. Bir diğer öğretmen ise her basamağın kendine ait bir değeri olduğunu öğrenciyi tahtaya çıkararak verilen sayıyı heceleyerek okumasını isteyeceğini ve böylece öğrencinin kendi hatasını kendisinin görebileceğini dile getirmiştir. Bu öğretmenin öğrenci merkezli bir yaklaşım sergilediği söylenebilir.

Bir diğer yanılgı olan "ondalık sayılarda ondalık yerler arasındaki ilişkiyi belirleyememe" ile ilgili öğretmenler, öğrencilerin basamak değer konusunu tam olarak anlayamadıklarını, basamak isimlerini bilmediklerini, öğrencinin ezberci yöntemi benimsemiş olduğu, denklem sistemi zihniyetinin çocuklara tam olarak öğretilmediği için ve sayıların okunuşunda yapılan hataların öğrencileri bu tarz yanılgılara itebileceğini dile getirmişlerdir. Brown'un (1981) araştırmasında sorulan "2,9'a bir ondalık ekleyin" sorusuna bazı öğrenciler 2,19 (ondalığa on ekle 19 elde edeceksin) bazı öğrenciler de 2,10 (dokuz üzerine bir ekle) yanıtını vermişlerdir (Ubuz ve Arslan, 2009, s.113). Aynı zamanda Uça'nın (2014) 17 dördüncü sınıf öğrencilerinin ondalık kesirlerin basamak adlarını belirtmelerine ilişkin öğretim öncesi bilişsel süreçlerini ön ve son klinik görüşmelerde verdikleri cevaplar doğrultusunda incelemiş ve tüm öğrencilerin ondalık kesirlerin basamak adlarını belirleyemediklerini görmüştür. Bu bağlamda araştırmanın bu bulgusu Brown ve Uça'nın bulgularını destekler nitelikte olduğu söylenebilir. Öğretmenlerin çoğunluğunun bu yanılgı karşısında benzer görüşlere sahip oldukları belirlenmiştir. Öğretmenlerin bu yanılgı 
karşısında uygulayacağı yollar; basamak değer konusunu kısa bir hatırlatma, uzunluklar arasındaki farkı görsel olarak göstererek öğrencilerin muhakeme yapmalarına olanak sağlama ve günlük hayattan örnekler verme olarak sıralanabilir.

Öğretmenler, "sıfırın basamakta yer tutucu olması özelliği ve kullandığımız sistemin yazı dilinde ve sözel dilde farklılık göstermesi” yanılgısına ilişkin öğrencinin ilköğretim birinci kademe yıllarında sayıların okunuşu-yazılışı konusunu ve sıfırın basamakta yer tutucu olması özelliğini kavrayamadıklarını belirtmişlerdir. Özellikle bu konuda alıştırma eksikliklerinin olduğunu, öğrencilerde basamak ve sayı kavramlarının tam oturmadığını ve yazı dili ile sözel dilin farklılığından kaynaklı öğrenci güçlüklerine dikkat çekmişlerdir. Öğretmenlerin bu yorumları Sharma (1993)'nın araştırması ile paralellik göstermektedir. Öğrenciler için sıfırı, "hiçbir şey" i göstermek için kullanmak o kadar zor olmasa da basamak değeri sisteminde kullanmak çok zordur (Sharma, 1993). Öğretmenler, öğrencilerdeki bu yanılgı karşısında farklı örnekler üzerinde sıfııın değerli olduğunu öğrencilere göstermeleri dışında farklı yaklaşımlar da sergilediklerini dile getirmişlerdir. Bir öğretmen okulda bulunan birlik, yüzlük, binlik kartları sınıfa getirerek görsel öğretimin daha etkili olacağını vurgularken, bir diğer öğretmen öğrencinin yanlış yazdığı sayıyı çözümlemesini isteyerek öğrencinin yaptığı hatayı kendisinin görmesinin etkili olacağını dile getirmiştir. Eğitimde aile etkeninin önemi üzerinde duran bir öğretmen ise aile bireylerinin yardımı ile öğrencinin konu ile ilgili daha çok alıştırma yapması gerektiği üzerinde durmuştur.

Öğretmenler, öğretmenlik yaşamlarında basamak değer konusu ile ilgili kavram yanılgılarına sıkça rastladıklarını dile getirmişlerdir. En sık karşılaşılan yanılgının basamak değeri kavramının eksikliğinden kaynaklanan ondalık sayılar konusunda görüldüğünü belirtmişlerdir. Aynı zamanda öğrencilerin basamak değer kavramının eksikliğinden oluşan ondalık sayılarda ve tam sayılarda bölme işlemlerinde güçlükler yaşadıklarını vurgulamışlardır.

Öğretmenlerin bu yorumları incelendiğinde katılımcı öğretmenler basamak değer konusunun öğrenimine ilişkin uluslararası literatürdebulunan bulgu ve düşüncelerle kapsam ve içerik olarak oldukça benzer ve zengin bilgiler geliştirdikleri görülmektedir. Katılımcı öğretmenlerin uluslararası literatürü takip etme imkanlarının olmadığını düşünürsek bu bilgileri kendi mesleki yaşamları boyunca yapmış oldukları gözlemler ve öğrencilerinin düşünme sistematikleri üzerinde yürütmüş oldukları pedagoji içerikli yoğun düşünsel aktiviteler sonucunda geliştirmiş olabilecekleri söylenebilir (Bayazit ve Aksoy, 2010).

Sonuç olarak, matematiğin önemli bir konusu olan basamak değer kavramına ilişkin öğretmenlerin farkındalıklarını artırmak umut edilmektedir. Bu bağlamda öğretmenlere basamak değer kavramı üzerinde önemle durmaları önerilebilir. Öğretmenlerin öğrencilerdeki bu güçlüklerin giderilmesinde pedagojik bilgilerinin önemi yadsınamayacak kadar büyüktür. Bu nedenle burada sunulan çalışmanın bir benzerinin daha fazla katılımcıyla ve farklı matematik konuları bağlamında yapılması gerekmektedir. Basamak değer kavramına ilişkin öğrencilerde hedeflenen düşünce 
değişiminin oluşumunda sınıf içi öğretimlerin materyal ve teknoloji kullanımlarıyla desteklenmesi önerilebilir.

\section{Kaynaklar}

Arslan, S., Yıldız, C. ve Yavuz, İ. (2011). Basamak Değeri Kavramının Öğretim Durumlarının İncelenmesi. e-Journal of New World Sciences Academy Education Sciences, 6(1), 490-507.

Bayazit, İ. ve Aksoy, Y. (2010). Öğretmenlerin Fonksiyon Kavramı ve Öğretimine İlişkin Pedagojik Görüşleri. Gaziantep Üniversitesi Sosyal Bilimler Dergisi, 9(3), 697-703.

Baki, A. ve Güç, F. A. (2014). Dokuzuncu Sınıf Öğrencilerinin Devirli Ondalık Gösterimle İlgili Kavram Yanılgıları. Turkish Journal of Computer and Mathematics Education,5(2), 176-206.

Brown, M. (1981). Place Value and Decimals. K. M. Hart (Ed.), Children's Understanding of Mathematics, 11(16), 48-65.

Dinç Artut, P. ve Tarım, K. (2006). İlkögretim Ögrencilerinin Basamak Deger Kavramını Anlama Düzeyleri. Egitimde Kuram ve Uygulama Dergisi, 2(1), 2636.

Dede, Y., Bayazit, İ. ve Soybaş, D. (2010). Öğretmen Adaylarının Denklem, Fonksiyon ve Polinom Kavramlarını Anlamaları. Kastamonu Eğitim Dergisi, 18(1), 67-88.

Ekiz, D. (2004). Eğitim Dünyasının Nitel Araştırma Paradigmasıyla İncelenmesi: Doğal ya da Yapay. Türk Eğitim Bilimleri Dergisi, 2(4).

Erduran, A. ve Yeşildere, S. (2010). Geometrik Yapıların İnşasında Pergel ve Çizgecin Kullanımı. İlköğretim Online, 1(9), 331-345.

Fuson, K. C. ve Bariars, D. J. (1990). Using a base-ten block learning/teaching approach for first and second grade place value and multidigit and subtracion. Journal for Research in Mathematics Education, 21,180-206.

Kaplan, H. A. (2008).İlköğretim Sekizinci Sınıf Öğrencilerinin "Basamak" ve "Basamak Değeri" Kavramları İle İlgili Zihinsel Yapılarının İncelenmesi. Yayımlanmamış yüksek lisans tezi, Gazi Üniversitesi Eğitim Bilimleri Enstitüsü, Ankara.

Kamii, M. (1982). Place Value: An Explanation of Its Difficulty and Educational Implications for the Primary Grades. Journal of Research in Childhood Education, 1(2), 75-86.

Karataş, İ. ve Güven, B. (2003). 8. Sınıf Öğrencilerinin Problem Çözme Becerilerinin Belirlenmesi: Bir Özel Durum Çalışması, Milli Eğitim Dergisi, 134. 
Park, S. ve Oliver, J. S. (2008). Revisiting the Conceptualisation of Pedagogical Content Knowledge (PCK): PCK as a Conceptual Tool to Understand Teachers as Professionals, Research in Science Education, 38, 261-284.

Sharma, M. C. (1993). Place Value Concept: How Children Learn It and How to Teach İt.Math Notebook, 10(1-2), 1-26.

Steinle, V. (2004). Changes with Age in Students' Misconceptions of Decimal Numbers. Yayınlanmamış doktora tezi, The University of Melbourne.

Tekkaya, C. ve Kılıç, D.S. (2012). Biyoloji Öğretmen Adaylarının Evrim Öğretimine İlişkin Pedagojik Alan Bilgileri. Hacettepe Üniversitesi Eğitim Fakültesi Dergisi, 42, 406-417.

Thompson, I. (2002). An İnvestigation of the Relationship Between Young Childeren's Understanding of the Concept of Place Value and Their

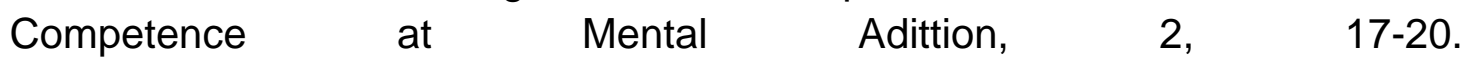
http://www.ianthompson.pi.dsl.pipex.com adresinden 7 Mayı 2011 'de alınmıştır.

Thompson, I. (2003). Putting place value in its place, Mathematics Teaching, 184, 14-15.

Ubuz, B. ve Arslan, S. (2009). Sayılarda Basamak Değeri Kavramı ve Öğrencilerin Yaşadığı Zorluklar. E. Bingölbali ve M.F. Özmantar (Editörler), İlköğretimde Karşılaşılan Matematiksel Zorluklar ve Çözüm Önerileri, Ankara: Pegem Akademi Yayıncılık, 135-138.

Uça, S. (2014). Öğrencilerin Ondalık Kesirleri Anlamlandırmasında Gerçekçi Matematik Eğitimi Kullanımı: Bir Tasarı Araştırması. Yayımlanmamış Yüksek Lisans Tezi, Adnan Menderes Üniversitesi Sosyal Bilimler Enstitüsü, Aydın.

Van Driel, J.H., Berjaard, D., \& Verloop, N. (2001).Professional Development and Reform in Science Education:The Role of Teachers' Practical Knowledge. Journal of Research in Science Teaching, 38, 137-158.

Varol, F. ve Kubanç, Y. (2012). Öğrencilerin Dört İşlemde Yaşadıkları Yaygın Aritmetik Güçlükler. International Periodical For the Languages, Literature and History of Turkish or Turkic,7(1), 2067-2074.

Yenilmez, K. ve Yaşa, E. (2008). İlköğretim Öğrencilerinin Geometrideki Kavram Yanılgıları. Eğitim Fakültesi Dergisi, 21(2), 463.

Yenilmez, K. ve Demirhan, H. (2013). Altıncı Sınıf Öğrencilerinin Bazı Temel Matematik Kavramları Anlama Düzeyleri. Dicle Üniversitesi Ziya Gökalp Eğitim Fakültesi Dergisi, 20, 275-292. 